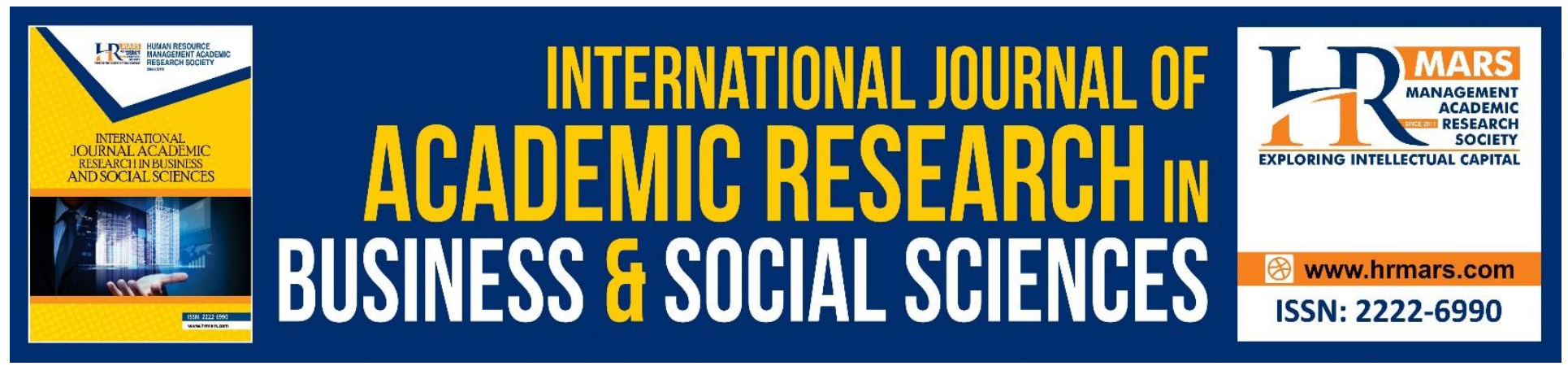

\title{
21 st Century Learning of History and Citizenship Values: A Conceptual Paper
}

\section{Shakila Che Dahalan, Abdul Razaq Ahmad}

To Link this Article: http://dx.doi.org/10.6007/IJARBSS/v8-i11/5336

DOI: $10.6007 /$ IJARBSS/v8-i11/5336

Received: 14 Oct 2018, Revised: 21 Nov 2018, Accepted: 28 Nov 2018

Published Online: 03 Dec 2018

In-Text Citation: (Dahalan \& Ahmad, 2018)

To Cite this Article: Dahalan, S. C., \& Ahmad, A. R. (2018). 21st Century Learning of History and Citizenship Values: A Conceptual Paper. International Journal of Academic Research in Business and Social Sciences, 8(11), 1624-1631.

\section{Copyright: (c) 2018 The Author(s)}

Published by Human Resource Management Academic Research Society (www.hrmars.com)

This article is published under the Creative Commons Attribution (CC BY 4.0) license. Anyone may reproduce, distribute, translate and create derivative works of this article (for both commercial and non-commercial purposes), subject to full attribution to the original publication and authors. The full terms of this license may be seen

at: http://creativecommons.org/licences/by/4.0/legalcode

\section{Vol. 8, No. 11, 2018, Pg. 1624 - 1631}

Full Terms \& Conditions of access and use can be found at http://hrmars.com/index.php/pages/detail/publication-ethics 


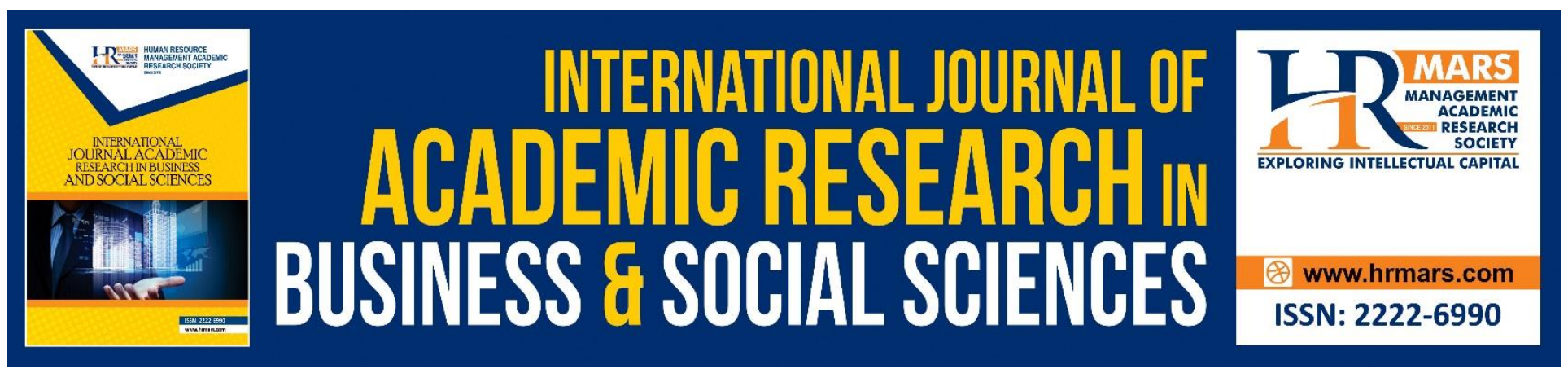

\title{
21 st Century Learning of History and Citizenship Values: A Conceptual Paper
}

\author{
Shakila Che Dahalan \\ Faculty of Education, The National University of Malaysia \\ Abdul Razaq Ahmad \\ Faculty of Education, The National University of Malaysia
}

\begin{abstract}
This study aims to look at the influence of 21st century learning of history on students' citizenship values. Furthermore, this study also looks at students' perceptions towards 21st century learning of history as a link to the students' citizenship value. This study will focus on five aspects of citizenship values, namely supporting the principles and values of democracy, emotional attachment towards one's country, sense of belonging, patriotic values and self-identity. This study will add an analytical study related to 21 st century learning of history $(21 \mathrm{LH})$ and students' citizenship values to which far too little attention has been paid in previous studies. The participants of the study will consist of secondary school students in Malaysia. The findings of the study will be analyzed using structural equation modeling (PLS-SEM). The implication of this study is that the findings from this current study will contribute by adding to the growing body of the current literature relating to researches on the influence of 21st century learning of history on citizenship values among students in Malaysia.
\end{abstract}

Keywords: $21^{\text {st }}$ Century Learning of History, Citizenship, History Education.

\section{Introduction}

History education is now facing challenges because it is now in a period where information is easily found on the fingertips. Students today are oriented towards the use of technology-driven gadgets in their lives. The challenging world is currently giving a great blow to history education as it is under the influence of rapidly growing technology, and therefore, the contents of history lessons involving events that have occurred thousands of years ago should be able to achieve the learning goals of history and not only attract students' interest. The emphasis and mastery of 21st century skills in the teaching and learning process needs to be clear so that learning objectives can be achieved by students. Therefore, the curriculum of history education in Malaysia through the Secondary School Standards Curriculum (KSSM) has presented the 21st century learning for the subject of history in 
INTERNATIONAL JOURNAL OF ACADEMIC RESEARCH IN BUSINESS AND SOCIAL SCIENCES Vol. 8, No. 11, Nov, 2018, E-ISSN: 2222-6990 @ 2018 HRMARS

order to achieve equivalency among students in the aspects of knowledge, skills and citizenship values (Ministry of Education, 2015).

21st century learning of history is a form of learning process in historical subjects that involves five types of skills, namely communication, collaboration, creativity, critical thinking and information literacy in order to produce students who would do well in life, have digital literacy skills, and be wellrespected as responsible citizens (Saucerman et al., 2017; Osler \& Starkey, 2018). Studies which are related to 21st century learning have become a great concern in educational conferences, and educational journals both locally and internationally. Based on search results in Google Scholar, as of August 2018 , as many as 35,660 studies related to 21 st century learning have been published in journals and books online (Google Scholar, 2018).

Table 1. Number of research studies

\begin{tabular}{|l|l|l|l|}
\hline Year /Issue & Malay Publications & English Publications & Total Number of Studies \\
\hline $\begin{array}{l}\text { August } \\
2018\end{array}$ & 2760 & 32,900 & 35,660 \\
\hline 2017 & 5630 & 46,800 & 52,430 \\
\hline 2016 & 5030 & 59,200 & 64,230 \\
\hline 2015 & 3310 & 61,500 & 64,810 \\
\hline 2014 & 2130 & 69,800 & 71,930 \\
\hline 2013 & 1980 & 75,100 & 77080 \\
\hline
\end{tabular}

Source: Google Scholar, (2018)

This is because nowadays many people in the field of education see the needs and importance of the 21st century learning to be introduced to students. This is supported by Ester et al., 2017, Scherer et al., 2017 and Owen et al., 2016 that 21st century learning is a contemporary way of learning which connects the learning environment of students in the classroom with their involvement in their career, life, and nation.Consequently, In this study, four of the 21st century learning skills will focus on communication skills, collaboration skills, creativity skills, critical thinking skills and information literacy skills that connect five aspects of students' citizenship values, namely supporting the principles and values of democracy, emotional attachment towards one's country, sense of belonging, patriotic values and self-identity (Ministry of Education Malaysia 2015a).

Previous studies have shown positive links between 21st century learning and communication skills, collaboration, creativity, critical thinking and students' information literacy (Hwang et al., 2018; Barak, 2017). Positive relationships occur because students are given opportunities to give ideas, and communicate views among classmates, and their assignments are exhibited in the classroom. This will influence students to provide commitment in fulfilling the aspirations of historical education. The aspirations of historical education consists of three main aspects of cognition, namely knowledge, skills of historical thinking and the value of citizenship (Ministry of Education Malaysia 2015a). However, the study only focused on the aspect of cohesion in citizenship values.

The concept of citizenship values is not easy to be specifically defined by researchers. According to Merry (2018) and Giersch and Dong (2018), citizenship includes political rights, social 
rights, laws, sense of belonging, and voluntary involvement of individual volunteers. The aspect of voluntary involvement of individual volunteers was supported by Mohd Mahzan Awang, (2015) who added that a good citizenship is assessed based on intellectual skills, critical thinking and active involvement of each individual voluntarily.According to Ministry of Education Malaysia (2015), the definition of citizenship values intended for students involves the value of supporting the principles and values of democracy, emotional attachment to the nation, sense of belonging, patriotism and self-identity.

The education system is one of the aspects as a channel to shape good citizenship values among the younger generation. Education of citizenship values that affects students will form a generation with faith in god, knowledgeable, noble character, self-esteem, society and nation. Citizens who have high citizenship values also feel a high sense of belonging to the nation. This situation will lead to increased self-esteem of the people in implementing their values and contributing to the workplace, life and nation.

\section{Problem Statement}

In recent years, there has been an increasing number of studies related to 21st century learning. Nevertheless, there is still insufficient data for studies on 21st century learning of history locally and abroad, especially studies which involve aspects of students' values. Although there are some studies related to 21st century learning of history such as by Hashim and Idris (2016) who studied contribution of teaching aids for history subject in comic form; Zunaida Zakaria et al. (2018) who examined teacher's supporting environment in teaching history; and Nasibi (2015) who reviewed the contents of the history curriculum which is biased to the Euro-Centric view, in most of these studies, far too little attention has been paid to students' citizenship values from the aspects of supporting the principles and values of democracy, emotional attachment towards one's country, sense of belonging, patriotic values and self-identity

In addition, most of the previous studies have involved participants from overseas and have not included researches on 21st century learning of history in Malaysia.

It is undeniable that to date researches have been carried out on the relationship between 21st century learning of history and citizenship values such as by Marcus et al., (2018) ; Voet, (2017) and Owen et al., (2016). However, these researches have only been carried out in Western context which involved students from foreign countries. The need for this study is to examine the relationship between 21st century learning of history and Malaysian students' citizenship values and perceptions towards 21st century history of history according to Malaysian context. Therefore, this current study on relationship between 21st century learning of history and students' citizenship values need to be carried out in order to meet the gaps in this field of study. 


\section{Citizenship values}

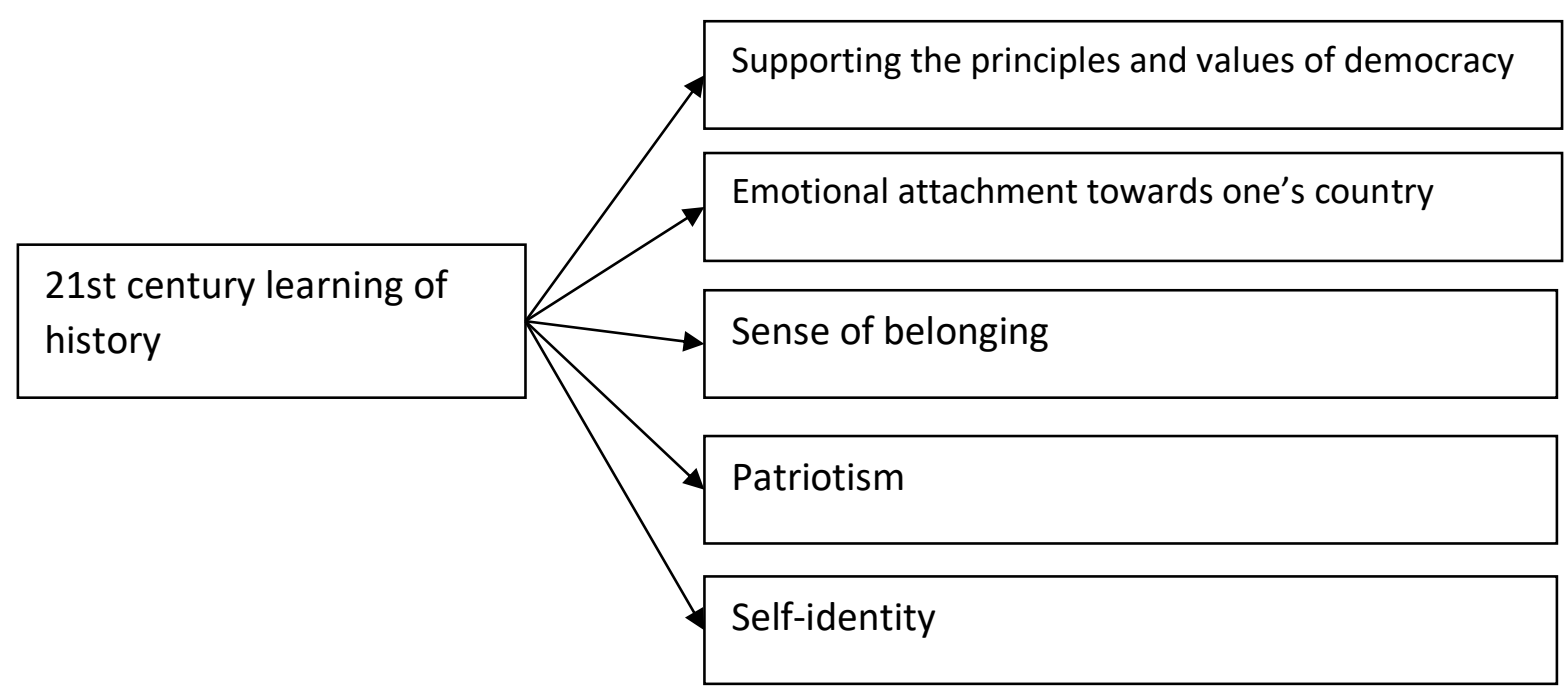

\section{Research Questions}

Figure 1. Proposed Conceptual Framework

1) What is the correlation between $21^{\text {st }}$ century learning of history and citizenship values in term of supporting the principles and values of democracy?

2) What is the correlation between $21^{\text {st }}$ century learning of history and citizenship values in term of emotional attachment towards one's country?

3) What is the correlation between $21^{\text {st }}$ century learning of history and citizenship values in term of sense of belonging?

4) What is the correlation between $21^{\text {st }}$ century learning of history and citizenship values in term of patriotic values?

5) What is the correlation between $21^{\text {st }}$ century learning of history and citizenship values in term of self-identity?

\section{Research Objectives}

1) Determining the relationship between 21st century learning of history and citizenship values in term of supporting the principles and values of democracy.

2) Determining the relationship between 21st century learning of history and citizenship values in term of emotional attachment towards one's country.

3) Determining the relationship between 21st century learning of history and citizenship values in term of sense of belonging.

4) Determining the relationship between 21st century learning of history and citizenship values in term of patriotic values. 
5) Determining the relationship between 21st century learning of history and citizenship values in term of self-identity.

\section{Research Hypotheses}

1) There is no significant relationship between 21st century learning of history and citizenship values in term of the aspects of supporting principles and values of democracy.

2) There is no significant relationship between 21st century learning of history and citizenship values in term of the aspects of emotional attachment towards one's country.

3) There is no significant relationship between 21st century learning of history and citizenship values in term of the aspects of sense of belonging.

4) There is no significant relationship between 21st century learning of history and citizenship values in term of the aspects of patriotic values.

5) There is no significant relationship between 21st century learning of history and citizenship values in term of the aspects of self-identity.

\section{Methodology}

To determine the relationship between two variables, namely 21st century learning of history and students' citizenship values, quantitative methods are used by researchers in order to provide a summary of data that will be generalized in this study. As this current study will determine the relationship between the two variables about which there has been little discussion so far, cross sectional survey design and exploratary based study will be used as the methodology in this study.

Sampling and data collection procedures are as below.

Table 1. Data Collection and Data Collection Procedures

\begin{tabular}{|l|l|}
\hline Data Population & Higher Secondary School Students \\
\hline Sample of Study & Form 4 Students \\
\hline $\begin{array}{l}\text { Sampling } \\
\text { Method }\end{array}$ & Convenience sampling method \\
\hline $\begin{array}{l}\text { Data Collection } \\
\text { Method }\end{array}$ & Distribution of questionnaires \\
\hline
\end{tabular}

\section{Data Analysis}

Most of the studies related to the effect of the relationship between the variables are carried out by Bolt et al. (2017) and Ali et al. (2018) who used structural equation modelling (PLS-SEM) as their research analysis. The results of PLS-SEM analysis in the form of a diagram model can describe the relationship between the variables of the study and test a variable by using confirmatory factor analytic (CFA) as the measurement model (Byrne \& van de Vijver, 2017). The higher the Construct reliability coefficient and the variance extracted, the more reliable the measurement model. The 
value of Construct reliability coefficient and variance extracted less than 0.5 for a research instrument is indicated as appropriate (Hair, Black, Babin, \& Anderson, 2014).

This study has used a structural model and will test the hypothesis of the study whether it is accepted or rejected. The structure of the study model will be validated through three indicators namely the determination coefficient (R2), the effect size (f2), the prediction relation (Q2), the size and significance of the path coefficient. The decision whether to accept or reject the proposed hypothesis will depend on the decision of path coefficient, $p$-value and t-value with the importance level of 0.05.

\section{Conclusion}

In conclusion, this study examined the relationship between 21st century learning of history and the characteristics of students' citizenship values. This study will prove the theoretical and scientific findings of the relationship between these two variables in the context of the implementation of history education in Malaysia.

\section{Acknowledgement}

The authors would like to acknowledge Pusat Zakat Selangor (UKM) for funding this study.

\section{Corresponding Author}

Shakila Che Dahalan, Faculty of Education, The National University of Malaysia, Malaysia.

Email: shakila1212@gmail.com

\section{References}

Ali, F., Rasoolimanesh, S. M., Sarstedt, M., Ringle, C. M., \& Ryu, K. (2018). An assessment of the use of partial least squares structural equation modeling (PLS-SEM) in hospitality research. International Journal of Contemporary Hospitality Management, 30(1), 514-538. https://doi.org/10.1108/IJCHM-10-2016-0568.

Barak, M. (2017). Science Teacher Education in the Twenty-First Century: a Pedagogical Framework for Technology-Integrated Social Constructivism. Research in Science Education, 47(2), 283-303. https://doi.org/10.1007/s11165-015-9501-y.

Bolt, T., Prince, E., Nomi, J. S., Messinger, D., Llabre, M. M., \& Uddin, L. Q. (2017). Combining region and network level brain behavior relationships in a structural equation model. Neurolmage. https://doi.org/10.1016/j.cmi.2017.11.021.

Byrne, B. M., \& van de Vijver, F. J. R. (2017). The maximum likelihood alignment approach to testing for approximate measurement invariance: A paradigmatic cross-cultural application. Psicothema, 29(4), 539-551. https://doi.org/10.7334/psicothema2017.178

Ester, van L., Alexander, van D. J. A. M., Jan A.G.M, van D., \& Haan, J. de. (2017). The relation between 21st-century skills and digital skills: A systematic literature review. Computers in Human Behavior, 72, 577-588. https://doi.org/10.1016/j.chb.2017.03.010.

Giersch, J., \& Dong, C. (2018). Required civics courses, civics exams, and voter turnout. The Social Science Journal, 55(2), 160-170. https://doi.org/10.1016/j.soscij.2017.09.002 
INTERNATIONAL JOURNAL OF ACADEMIC RESEARCH IN BUSINESS AND SOCIAL SCIENCES

Vol. 8, No. 11, Nov, 2018, E-ISSN: 2222-6990 @ 2018 HRMARS

Google Scholar. (2018). Google Scholar. Retrieved from https://scholar.google.com/scholar?hl=en\&as_sdt=0\%2C5\&q=21st+century+learning\&oq=21st

Hair, J., Black, W., Babin, B. J., \& Anderson, R. E. (2014). Multivariate data analysis 7th edition. United State: Pearson.

Hashim, M. E. A. H., \& Idris, M. Z. (2016). Theoretical Framework and Development Motion Comic Instrument as Teaching Method for History Subject, 6(11), 249-260.

Hwang, G. J., Lai, C. L., Liang, J. C., Chu, H. C., \& Tsai, C. C. (2018). A long-term experiment to investigate the relationships between high school students' perceptions of mobile learning and peer interaction and higher-order thinking tendencies. Educational Technology Research and Development, 66(1), 75-93. https://doi.org/10.1007/s11423-017-9540-3.

Kementerian Pendidikan Malaysia. (2015a). Kurikulum Standart Sekolah Menengah: Dokumen Standard Kurikulum dan Pentaksiran Sejarah. Putrajaya: Kementerian Pendidikan Malaysia.

Kementerian Pendidikan Malaysia. (2015b). kurikulum standart sekolah menengah. Putrajaya: Kementerian Pendidikan Malaysia. https://doi.org/10.15713/ins.mmj.3.

Marcus, A. S., Metzger, S. A., Paxton, R. J., \& Stoddard, J. D. (2018). Teaching history with film: Strategies for secondary social studies (2nd ed.). New York: Routledge Taylor and Francis Group.

Merry, M. S. (2018). Can schools teach citizenship? Discourse, 6306, 1-15. https://doi.org/10.1080/01596306.2018.1488242.

Nasibi, M. W. (2015). A Critical Appraisal of History Taught in Secondary Schools in Kenya. International Journal of Academic Research in Progressive Education and Development, 4(1), 639-654. https://doi.org/10.6007/IJARPED/v4-i1/8.

Osler, A., \& Starkey, H. (2018). Extending the theory and practice of education for cosmopolitan citizenship. Educational Review, 30(1), 31-40. https://doi.org/10.1080/00131911.2018.1388616.

Owen, D., Doom, J. K., \& Riddle, G. I. W. (2016). Educating digital citizens: The influence of high school civics instruction. Annual Meeting of the Southern Political Science Association, 7-9.

Saucerman, J., Ruis, A., \& Shaffer, D. (2017). Automating the Detection of Reflection-on-Action. Journal of Learning Analytics, 4(2), 212-239. https://doi.org/10.18608/jla.2017.42.15.

Scherer, R., Tondeur, J., Siddiq, F., \& Baran, E. (2017). The importance of attitudes toward technology for pre-service teachers' technological, pedagogical, and content knowledge: Comparing structural equation modelling approaches. Computer in Hutan Behavior. https://doi.org/10.1016/j.micron.2014.02.010.

Voet, M. (2017). Inquiry-based learning in history education: Exploring teachers' beliefs, knowledge, and use of technology, and preparing future teachers for implementation in class. Ghent University.

Zakaria, Z. Ahmad, A. R. \& Awang, M. M. (2018). Teachers' Environmental Support in the Implementation of History Subject. International Journal of Academic Research in Business and Social Sciences, 8(4), 500-507. https://doi.org/10.6007/IJARBSS/v8-i4/4028. 